\title{
The False Door of Shepsi at the Egyptian Museum of Cairo
}

\section{Taher Abdelhamid}

Faculty of Tourism and Hotels, Fayoum University.

\section{Abstract}

The Memphite necropolis was the site which provide numerous false doors dating to Old Kingdom. The limestone false door of Shepsi was discovered in Saqqara and conserved now in

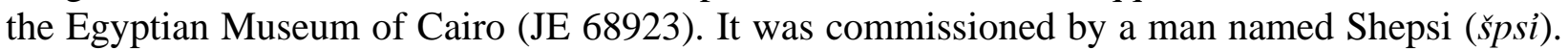
This research aims to publish this false door, to indicate its characteristics and to date. According to its shape, inscribed titles and costumes, this false door could be dated to fifth Dynasty.

Keywords: False door, Shepsi, Cairo Museum, Titles, Inscriptions.

\section{Introduction}

The false door of Shepsi was found at Saqqara. This necropolis measures six kilometers from the North to the South ${ }^{1}$. The earliest royal name which the archeologists have so far found at Saqqara is the name of Narmer (Menes) ${ }^{2}$. From that time, it was used for over three thousand years when finally demolished with the burial of the monks of the monastery of Apa Jeremais ${ }^{3}$.

Saqqara necropolis is divided into six sectors: the North, the Middle, Teti pyramid, the Western, Unas pyramid, and the Southern sector ${ }^{4}$. Shepsi false door is discovered by Emery for the Egyptian Antiquities in his tombs (S 3302) around the Step pyramid of Zoser in the middle sector of Saqqara 5 .

The false door was an architectural element that is found in private tombs structure and the mortuary temples of the pyramid. It was imitating the Egyptian real door, but it had no entrance to any interior space. It begun probably from the archaic period and attested from the second and the third Dynasty in Saqqara birthstone mastaba. It was used as an imaginary passage for the deceased and providing him with the funeral repast ${ }^{6}$.

The studied false door was listed among the archeological pieces coded in Porter and Moss (III ${ }^{2}$, 443). Furthermore, Gardiner in his notebooks mentioned the text of the lintel only, and Smith in his book "History of Egyptian Sculpture and Painting in the Old Kingdom" listed it in his footnote (p. 150). Despite the data had given, this false door wasn't studied in scientific research. This paper aims to publish the false door of Shepsi in the Egyptian Museum of Cairo; analyzing the iconography of this false door through comparative study; as well as the inscription; and finally giving an academic analysis explaining the dating of the false door.

\section{Description of the false door}

(Fig. 1, 4)

This false door, in the Museum's database, was listed under JE 68923 and SR2/14872. It measures $190 \mathrm{~cm}$ high and $155 \mathrm{~cm}$ wide. It is made out of limestone.

\footnotetext{
${ }^{1}$ K. Daoud, Corpus of Inscriptions of the Herakleopolitan Period from the Memphite Necropolis, BAR International Series 1459, Oxford, 2005, p. 7.

${ }^{2}$ W. Helck, "Narmer", in: Helck, W., and Otoo, E., (eds.), Lexicon der Ägyptologie, Vol. IV, Otto Harrassowitz and Wiesbaden, 1982, pp. 348- 50; H. Bruner, "Menes", LÄ IV, pp. 46- 48.

${ }^{3}$ K. Daoud, Corpus of Inscriptions, P. 7

${ }^{4}$ V. Chauvet, "Saqqara", in: D. Redford, (ed.), the Oxford Encyclopedia of Ancient Egypt, Vol. III, Cairo, 2001, pp. 176- 179.

5 PM III/2, p. 443.

${ }^{6}$ Wiebach, S., "False Door" in: Redford, D. (ed.), the Oxford Encyclopedia of Ancient Egypt, Vol. I, 2001, Oxford, pp. 498- 501.
} 


\section{The panel}

This door is a two-jamb door. The panel was destroyed except the remains of the deceased sitting on a bench that has animal paws. An offering table is depicted in front of him. The text on the

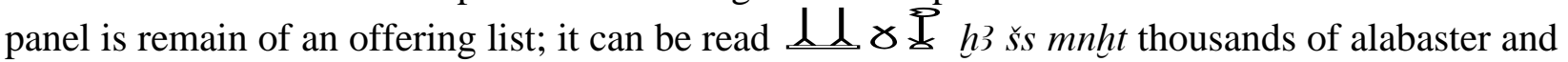
clothes, 8 \& $h 3$ b $3 b d h 3$ thousands of fowl, and thousands of .......

\section{The lintel}

On the lintel was inscribed by the title of the owner, from the right to the left, as follows

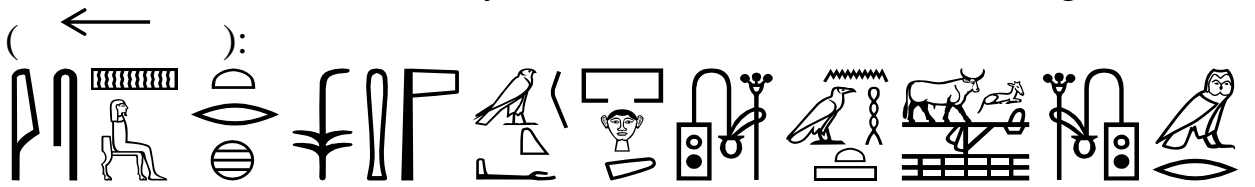

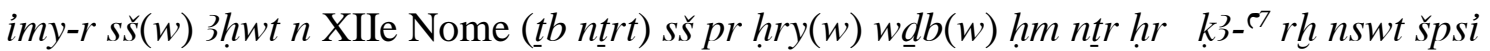

The overseer of land-scribe ${ }^{8}$ of Sebennite ${ }^{9}$, scribe of the house of the distribution (of offerings) ${ }^{10}$, Priest of Horus elevated of arm, he who is known to the king (royal acquaintance), Shepsi.

\section{The drum}

The drum has one title of Shepsi as follows $(\longleftarrow)$ :

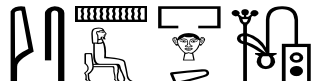

Scribe of the house of the distribution (of offerings), Shepsi.

\section{The jambs}

The plaster covering of outer jambs was falling, so it had no decorations or texts. The deceased is depicted on the right inner jamb; he is shown in a standing position with right leg advanced. He folded his right hand across his chest while holding the hrp scepter in his left hand by his side. He wears a kilt striped from the right and knotted on his waist. A close-fitting echelon-curl wig is worn on his head which covers the ears, a collar around his neck, and bracelets around his hands. The figure on the left inner jamb is similar to the other on the right one except the left leg is advanced and an amulet is shown around his neck. It can be noted that once the deceased advanced the right leg while the other extends the left, this is because they faced each other. Additionally, the ancient Egyptian artist used to represent the figures in profile with the outer leg advanced to show the best view of the portrayal ${ }^{11}$.

The text on the right jamb is shown from the left to right as follows ( $\rightarrow \quad$ ):

\footnotetext{
${ }^{7}$ Simpson as well as El-Khouli and Knawati read it kmз-`; W. K. Simpson, Giza mastabas vol. III, The mastaba of Kawab and Khaf Khufu I and II, Boston, 1980, p. 12; A. El-Khouli, and N. Kanawati, Quseir el-Amarna. The Tombs of Pepy-ankh and Khewen-wekh, (The Australian Centre for Egyptology. Report 1). Sydney, 1989; Jones added the word thnw to the title; D. Jones, An Index of Ancient Egyptian Titles, Epithets and Phrases of the Old Kingdom, vol. II, BAR International Series 886 (II), Oxford 2000, 561, 2077.

${ }^{8}$ Hassan translated this title as Overseer of the Scribes of the Cultivated Lands; S. Hassan, Excavation at Giza, vol. VII, 1935-36, The Mastaba of the seventh season and their description, Cairo, 1953, p. 101.

9 This Nome is Samanod today: N. de G. Davies, The Mastaba of Ptahhetep and Akhethetep at Saqqarah (ASE), vol. I, London, 1901, p. 66, pl. VI; Gauthier, H., Dictionnaire des Noms Géographiques Contenus dans les Textes Hieroglyphiques, vol. VII, Cairo, 1929, p. 74; P., Montet, Géographie de l'Éypte Ancienne, vol. I, Paris, 1951, p. 103-04.

${ }^{10}$ Jones translated it as scribes of the house/ department of those in charge of reversions (of offerings); Jones, An Index of Ancient Egyptian Titles, vol. I, p. 212 (790).

${ }^{11}$ E. Teeter, "Egyptian Art" in: Art Institute of Chicago Museum Studies, Vol. 20, 1994, p.13; F. Rose, The Art of Ancient Egypt, New York, 2002, p. 43.
} 


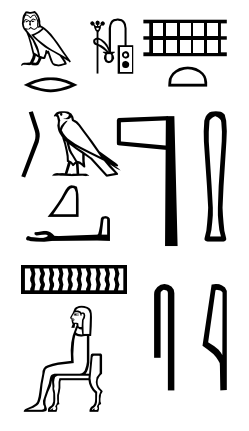

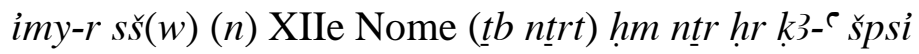

The overseer of scribe of Sebennite, Priest of Horus elevated of arm, Shepsi.

The text in the left inner jamb is faced the other on the right as follows $(\downarrow \leftarrow)$ ):

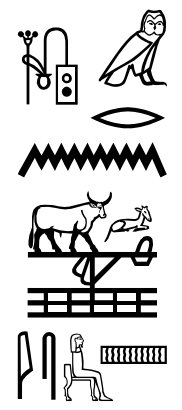

imy-r š̌s $(w)(n)$ XIIe Nome (țb ntrt) špsi

The overseer of scribe of Sebennite, Shepsi.

\section{The statue of Shepsi}

(Fig. 2)

The statue was made out of limestone. Its height is $120 \mathrm{~cm}$. It was supported by a pillar that reached its shoulder. Shepsi is depicted standing with the right leg advanced. He fists a cylindrical object on his hands. He wears a striated wig parted in the center reaching to just above shoulder length and reveals the ear ${ }^{12}$. He wears a kilt around his lower part until his knees. The kilt is stripped from the right part and knotted around his waist like the two scenes on the inner jamb. In addition, there is a representation of a flower on the belt of the kilt.

The artist is skillful enough in representing the details of the body such as the full face with wide eyes, collarbones, muscles, the details of the knees, leg bones, and the nails of his toes ${ }^{13}$.

On the pedestal of the statue (fig. 3), a title of the owner is written as follows (
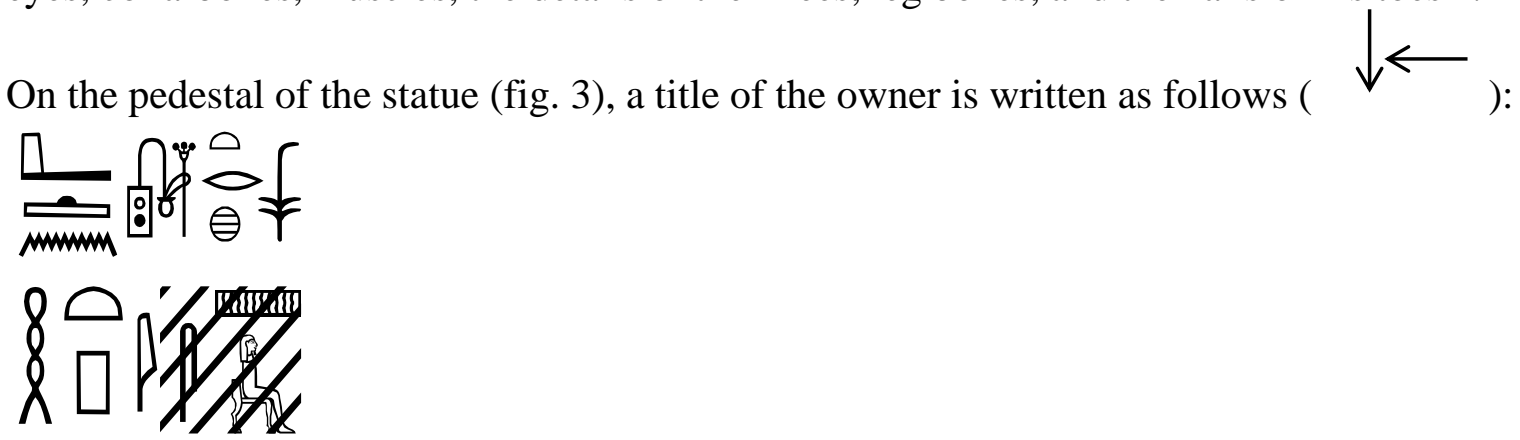

rht nswt šs kdt ntr n ptḥ spsi

${ }^{12}$ E. Staehelin, Untersuchungen zur ägyptischen Tracht im Alten Reich, MÄS 8, Berlin 1966, 88 E2.

${ }^{13}$ G. Perrot and Ch. Chipiez, The History of Art in Ancient Egypt, London, Vol. II, 1883, pp. 182- 83; C. Aldred, Old Kingdom Art in Ancient Egypt, London, 1949, pp. 13- 14. 
He who is known to the king (royal acquaintance ${ }^{14}$ ), the scribe of the divine book ${ }^{15}$ of Ptah, Shepsi.

\section{The titles of the Shepsi}

Shepsi has five titles; The first title is $i m y-r$ š̌ $(w) 3 h w t n$ XII ${ }^{\mathrm{e}}$ Nome ( $\underline{t} b$ n $\underline{t} r t$ ) the overseer of landscribe of Sebennite ${ }^{16}$ (Samanoud today). It was written on the false door of $h r n k 3 w$ from Giza from (IV - V) Dynasty ${ }^{17}$, while in the fifth Dynasty was inscribed on an offering table of $i t i^{18}$ at Egyptian Museum of Cairo (CG 1346). Moreover, the title imy-r š̌(w) 3hwwt without the name of the twelfth Nome appeared in the fifth Dynasty; it was inscribed on the statue of iti $(\mathrm{CG} 26)^{19}$, on the Double-statue of $n f r h t p$ and his wife in Cairo Museum (CG 89) ${ }^{20}$, It was written on the coffin of $n n h f t . k$ from Deshasheh ${ }^{21}$, on the unfinished false door of $h t p(\mathrm{C} 2)^{22}$, on the false door of $s h m$ $k 3(\mathrm{C} 19)^{23}$, and it appeared on Chamber A $d w 3 n r^{\mathrm{c}}(\mathrm{D} 61)^{24}$. Furthermore, it was appeared at the beginning of the sixth Dynasty in the tomb of Mereruka ${ }^{25}$.

The second title is $s \check{s}$ pr $h r y(w) w d \underline{d}(w)$ scribe of the house of those in charge of reversions (of offerings ${ }^{26}$. It has appeared in the fifth Dynasty on some block from tombs of whm k3, mry hwfw, and $h n m w$ ' $n h$ at Zawiet el- Mayetin ${ }^{27}$; on Chamber B of the tomb of $d w 3 n r^{c}$ (D 61) ${ }^{28}$, and on the false door of $d w^{3} n r^{\mathrm{c}}(\mathrm{H} \mathrm{15})^{29}$. In addition, this title was inscribed on the sarcophagus of $h t p i^{30}$, and on fragments from the tomb of $n f r k 3 w$ at Gebel Aboufodah ${ }^{31}$; all of them were dated to the end of the fifth Dynasty and the beginning of the sixth Dynasty. Furthermore, it was engraved on the wooden statue of $\underline{t} t i$ at Boston, Museum of Fine Arts (No. 24.607) during the reign of Pepi $\mathrm{II}^{32}$.

The third title is $h m n t r h r k 3^{3}{ }^{-33}$ Priest of Horus raised (strong ${ }^{34}$ ) of the $a^{2}{ }^{35}$. It appeared in the end of the fourth Dynasty; it was inscribed on the south wall of the tomb of $h^{\complement} h w f w^{36}(\mathrm{G} 7140)$.

${ }^{14}$ A. Hallström, the False Doors of Hershefnakht, Nyankhanty and Senetites, Uppsala 2017, P.1 8.

${ }^{15} \mathrm{P}$. Piacentini, Enquête sur les scribes dans la société Égyptienne de l'ancien Empire (les nécropoles Memphites), Vol. III, Paris, 1997, p. 1398.

16 Jones, An Index of Ancient Egyptian Titles, Vol. I, 207 (774); Murray, pl. XXIII.

${ }^{17}$ LD II, pl. 94 d.

18 A. Mariette, and G. Maspero, Les mastabas de l'ancien Empire, Paris, 1885, p. 437.

${ }^{19}$ L. Borchardt, Statuen und Statuetten, Catalogue Général des Antiquités Egyptiennes du Musée du Caire, vol. I, Berlin, 1911, pl. 7, p. 27; PM III/2, p. 450.

${ }^{20}$ Borchardt, Statuen, I, pl. 20, pp. 70-1; PM III/2, p. 451.

${ }^{21}$ W. F. Petrie, Deshasheh, London, 1898, P. 15, Pl. 29.

${ }^{22}$ Mariette, Mastabas, p. 115; PM III/2, p. 451.

${ }^{23}$ Mariette, Mastabas, p. 150; PM III/2, p. 465.

${ }^{24}$ Mariette, Mastabas, p. 349; PM III/2, p. 608.

${ }^{25}$ G. Daressy, Le mastaba de Mera, Cairo, 1900, p. 531.

${ }^{26}$ Jones, An Index of Ancient Egyptian Titles, vol. II, pp. 850-51 (3108); M.A. Murray, Index of Names and Titles of the Old Kingdom, BSAE 1, London, 1908, pl. XXXVIII.

${ }^{27}$ LD II, pl. 110 h; P. Piacentini, Zawiet el- Mayetin, Pisa, 1993, pp. 56, 99-100, 104; J.C. Moreno Garcia, Etudes sur l'administration, le pouvoir et l'idéologie en Egypte, de l'Ancien au Moyen Empire, Liege 1997, pp. 146- 47.

${ }^{28}$ Mariette, Mastabas, p. 349; PM III/ 2, p. 608.

${ }^{29}$ Mariette, Mastabas, p. 455.

${ }^{30}$ S. Hassan, Excavation at Giza, vol. V, 1933- 34, Cairo, 1944, p. 62, fig. 7; Hassan, Giza, VII, Cairo, 1953, p. 101; P. Piacentini, Scribes II, Paris, 1997, p. 388; P. Piacentini, Scribes III, Paris, 1997, p. 1358.

${ }^{31}$ Legrain, G., Notes Archéologiques prises au Gebel Abu Fodah, ASAE 1, 1899, p. 13.

${ }^{32}$ J. Harvey, Wooden Statues of the Old Kingdom, Boston, 2001, p. 371; Helck, Beanitentiteln, 31,68ff; Gardiner, JEA 24 (1938), 83-91.

${ }^{33}$ Helck suggested that this title was priesthood originally referred to the king, but later was identified with a local falcon god in the western Delta; W. Helck, Untersuchungen zu den Beamtentiteln des agyptischen Alten Reiches (AF18), Gliickstadt, 1954, 120 no. 3. 
In the fifth Dynasty, it was written on the west wall of the tomb of $s \check{m} n f r(\mathrm{I})^{37}$ (G 4940), on the false door of phn wi $k 3^{38}$ (D. 70, LS 15), on the lintel of the door which leads to the chapel of the

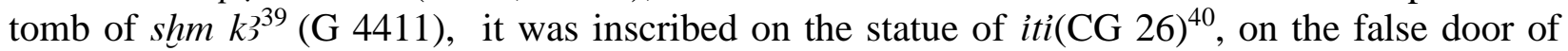
$k 3 i^{41}$ (D 19), and on the façade of the tomb of $h w n w h: t t i t^{42}$. In the sixth Dynasty, it was inscribed on the false door of $m 33 n f r^{43}$ (D37).

The fourth title of Shepsi is $r h$ nswt. The royal acquaintance ${ }^{44}$, one who is concerned with the things of the king ${ }^{45}$, custodian of the king's property ${ }^{46}$. It was the more important Honorific Titles in the Old Kingdom ${ }^{47}$; it was held by men as well as women ${ }^{48}$. It was entitled by $p h r n f r^{49}$ in the early of the fourth Dynasty, and held by $d w 3 r^{r 50}, i t t i^{51}$, and $p r s n^{52}$. In addition, it was entitled by mry pth mry $r^{-53}$ during the sixth Dynasty.

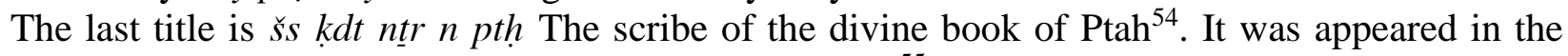
fourth Dynasty on the entrance of the tomb of $h^{e} . f m i n w^{55}$, and on the remains of the chapel of the tomb of $d w 3 n r^{e 56}$. Moreover, it was written in the fifth Dynasty; on the façade of the tomb of $t n t i^{57}$ (C 18), on the corridor of the tomb of $r^{c} m k^{3}{ }^{58}$ (D3), and on the Eastern wall of the tomb of wp $m n f r t^{59}$, while in the sixth Dynasty it was inscribed on the false door of $s s i^{60}$ (E 16), on the burial chamber of $\underline{h}^{\top} b 3 w \underline{h} n m w^{61}$, on the west wall of the tomb of $i b i$ at Dei El-Gebrawi ${ }^{62}$, and on the North wall of $\underline{h} t t i$ tomb at Dei El-Gebrawi ${ }^{63}$.

${ }^{34}$ E. de Rouge, Recherches sur les Monuments qu'on peut Attribuer aux Six Premières Dynasties de Manéthon. Paris 1866, p. 88 .

${ }^{35}$ Jones, an Index of Ancient Egyptian Titles, Vol. II, pp. 560- 62, (2075, 2077); Murray, Index, pl. XXIX.

${ }^{36}$ Daressy, Le Mastaba de khaefkhoufou a Gizeh, ASAE 16, 260, 257-67; Simpson, Giza Mastabas, III, p. 12; PM III, p. 188

${ }^{37}$ LD II, pl. 27; PM III, p. 142- 43; Piacentini, Scribes I, p. 303 and pl. 55.

${ }^{38}$ A. Weil, Die Veziere des Pharaonenreiches. Strasbourg, 1908, p. 7; LD II, 48; PM III/2, pp. 491-92.

${ }^{39}$ LD II, pl. 89 c; PM III, p. 127.

${ }^{40}$ Borchardt, Statuen, I, pl. 7, p. 27; PM III/2, p. 450.

${ }^{41}$ Mariette, Mastabas, p. 231; Weil, A., Die Veziere des Pharaonenreiches, p. 14; PM III/2, p. 479.

${ }^{42}$ A. El-Khouli, and N. Kanawati, Quseir el-Amarna, p. 34.

${ }^{43}$ Mariette, Mastabas, p. 266; PM III/2, p. 456.

${ }^{44}$ Jones, An Index of Ancient Egyptian Titles, Vol. I, p. 327 (1205).

${ }^{45}$ C. M. Firth, and B. Gunn, Teti Pyramid Cemeteries. Vol. I, Excavations at Saqqara, Cairo, 1926, p. 157 (6).

${ }^{46}$ A. Erman, and H. Grapow, (eds.) Wörterbuch der Ägyptischen Sprache im Auftrage der deutschen Akademien, vol. II, Leipzig and Berlin, 1971, 449 (9); R. Weill, Les origines de l' Egypte pharaonique. Première partie : Les I'e et III ${ }^{e}$ dynasties égyptiennes. Paris, 1908, p. 185- 86.

${ }^{47}$ N. Strudwick, The Administration of Egypt in the Old Kingdom. The Highest Titles and their Holders, London, 1985, p. 310 (table 30).

${ }^{48}$ Fischer, Egyptian Women, p. 15, nn. 132-3,

${ }^{49}$ PM III/2, p. 502., Strudwick, Administration, p. 85.

${ }^{50}$ PM III/2, p. 894; Strudwick, Administration, p. 163.

${ }^{51}$ Strudwick, Administration, p. 67.

${ }^{52}$ PM III/2, pp. 48-9; Strudwick, Administration, p. 84.

${ }^{53}$ PM III/2, p. 876; Strudwick, Administration, pp. 94-95.

${ }^{54}$ Jones, an Index of Ancient Egyptian Titles, vol. II, p. 857 (3132); Murray, pl. XXXVIII; N. Kanawati, and M. Abder-Raziq, The Teti Cemetery at Saqqara Vol. III. The Tombs of Efersheshemre and Seankhuiptah, Sydney 1998, p. 14(5), pl. 52.

55 PM III/1, p. 195; Strudwick, Administration, p. 122 (103).

56 PM III/1, p. 148.

${ }^{57}$ Mariette, Mastabas, p. 149; PM III/2, p. 482.

${ }^{58}$ Mariette, Mastabas, p. 179; PM III/2, p. 487.

${ }^{59}$ PM III/1, pp. 281- 82; S. Hassan, Excavation at Giza, vol. II, 1930- 31, Cairo, 1936, p. 179, fig. 219.

${ }^{60}$ Mariette, Mastabas, p. 420; PM III/2, p. 689.

${ }^{61}$ PM III/2, p. 684; Strudwick, Administration, p. 121 (102). 
$h r \mathrm{~kJ} / \mathrm{km}^{\mathrm{r}}$ has appeared between a name of an estate on the right thickness of the tomb of $h m w{ }^{c} n d ~ \check{s p s s} k 3 . f{ }^{C} n h^{64}$ which dates back to the end of fifth Dynasty or later ${ }^{65}$.

\section{Dating}

The name of the owner was not common during the Old Kingdom. It appears twice at Saqqara necropolis (tombs No. D13, and D 33), two of them dated to the fifth Dynasty ${ }^{66}$. In addition, it was mentioned one time during the sixth Dynasty ${ }^{67}$.

The titles of the deceased were common during the Old Kingdom between the $4^{\text {th }}$ and $6^{\text {th }}$ Dynasty, but the majority of people who held these titles were lived during the fifth Dynasty. Moreover, some of these titles were continued in the Middle Kingdom: such as: imy-r š̌s $(w) 3 h w t n$ XIIe Nome $(\underline{t} b n t r t)^{68}, \check{s} s k d t n t r n p t h^{69}$, and $s \check{s} p r h r y(w) w d \underline{d} b(w)^{70}$.

The style of the kilt (half-goffered kilt ${ }^{71}$, the so-called Galaschurz ${ }^{72}$ ) is similar to the kilt of $r^{r} n f r$ (CG 19) ${ }^{73}$, early to the fifth Dynasty ${ }^{74}$; the stripped part of the kilt is shown in the statues during the fifth Dynasty such as: $r^{e} w r^{75}$ (CG 29) and $r^{c} h t p(\text { CG 130) })^{76}$

The flower on the belt of the kilt was worn by men during the Old Kingdom, especially at Saqqara during in the fifth Dynasty such as: the statue of $k 3 m n s w t^{77}$, and the statue of $n i m 3^{\top} t$ $r^{r^{78}}$ (CG 51). Furthermore, in the six Dynasty the statues of $m t \underline{t} i^{79}$ (Brooklyn Museum, 50.77), $\mathrm{itti}^{80}$ (CG 47), and $k 3 \mathrm{~m} \mathrm{hst}{ }^{81}$ (JE 44174), had the flower in the middle of the kilt. They were from Saqqara.

${ }^{62}$ N. de G. Davies, The Rock Tombs at Deri El-Gebrawi, vol. I, London, 1902, pl. 8.

${ }^{63}$ N. de G. Davies, The Rock Tombs at Deri El-Gebrawi, vol. II, London, 1902, pl. 28.

${ }^{64}$ Hassan, Giza VI3, p. 85, Fig. 66; H. K. Jacquet-Gordon, Les noms des domaines funèraires sous Ancien Empire Égyptien (BdE 34). Cairo, 1962, p. 292.

${ }^{65} \mathrm{PM}$ III/1, p. 245.

${ }^{66}$ H. Ranke, Die ägyptischen Personennamen, vol. I, Glückstadt, 1935, p. 326; Mariette, Mastabas, pp. 207, 262; PM III/2, p. 457.

${ }^{67}$ A. Kamal,"Foullies À Dara et QoÇèir El-Amarna", ASAE 12, 1912, p. 142.

${ }^{68}$ CG 1640; W. Ward, Index of Egyptian Administrative and Religious titles of the Middle Kingdom, Beirut, 1982 , p. 46 (358).

${ }^{69}$ Strudwick, Administration, p. 161 (160); Ward, Index, p. 161 (1388).

${ }^{70}$ Ward translated it as Scribe of the House of the master of largesse; Ward, Index, p. 160, (1381).

${ }^{71}$ Harvey, Wooden Statues, p. 87.

72 J. Vandier, Manuel d' Archeologie Égyptienne, Tome III, les Grandes Époques la Statuaire, Paris, 1958, pp.108109; Staehelin, Tracht, 11-30,1 A 11(b); Eaton-Krauss,'Two Representations of Black-skinned Statues in Ancient Egyptian Painting", JARCE 13 (1976), 21-24.

${ }^{73}$ Borchardt, Statuen, i p. 19- 20, pl. 5; G. Steindorffe, Die Kunst der Ägypter, Leipzig, 1928, pp. 185-86; G. Perrot, and Ch. Chipiez, Histoire de L'art dans L'Antiquite, vol. I, L'Égypte, Paris, 1882, figs. 6

${ }^{74} \mathrm{PM}$ III/2, p. 462.

75 Borchardt, Statuen, I, pI. 8, p. 29; MARIETTE, Mastabas, p. 260.

76 PM III 2, 480; Borchardt, Statuen, I, pl. 29, p. 98;

${ }^{77}$ PM III/2, 543; Zayed, Trois ètudes, figs. 1- 3; Firth and Gunn, Teti Pyramid Cemeteries. vol. I, p. 31; Strudwick, Administration, 150-151; K. Baer, Rank and Title in the Old Kingdom. The Structure of the Egyptian Administration in the Fifth and Sixth Dynasties, Chicago, 1960, pp. 143-144 (528).

${ }^{78}$ PM III/2, 543; Borchardt, Statuen, I, pl. 13, pp. 45- 46; Mareitte, Mastsbas, p. 224.

${ }^{79} \mathrm{PM}$ III/2, 647; J. Vandier, Manuel d'Archéologie Égyptienne, pp. 90- 1, Pl. XXXV (1); P. Kaplony, Studien zurn Grab des Methethi, Bern, 1976, figs., on pp. 60- 61, cf. pp. 56 - 62; Harvey, Wooden statues, p. 185; Y. Harpure, Decoration in Egyptian tombs of the Old Kingdom, London and New York, 1987, p. 274.

${ }^{80}$ PM III/2, p. 598; Borchardt, Statuen, I, pI. 12, p. 43.

${ }^{81}$ PM III/2, 542; J. Quibell and A. G. K. Hayter, Excavation at Saqqara, Teti pyramid, North side, Cairo, 1927, pl. 29 , pp. $18,44$. 
The hair-wigs were common during the Old Kingdom; the close-fitting echelon-curled wig was depicted in scenes such as: the false door of $h^{\top} \cdot f r^{\complement}{ }^{\complement} n h^{82}(\mathrm{G} 7948)$, the west wall of the tomb of $s \check{s} t$ $h t p^{83}$, on the room III of $n f r b 3 w p t h^{84}$ (G 6010), and mmi tomb at El-Hawawish ${ }^{85}$ (M23); all of them date back from the fourth and fifth Dynasty.

The straight hair wig was shown in a lot of statues during the fifth Dynasty at Saqqara such as: the statue of the seated scribe ${ }^{86}$ (CG 36), the statue of $n i m 3^{r} t r^{r 87}$ (CG 51), the statue of snfrw $s n b^{88}$ (CG 137), unknown seated $\operatorname{man}^{89}$ (CG 92), double statues of two men ${ }^{90}$ (CG 168), and the statue of $r^{c} h t p^{91}$ (CG 185). In addition, there were some statues of the sixth Dynasty ${ }^{92}$ have straight hair wig as: $\mathrm{itti}^{93}$ (CG 47), $m 33$ nfr as a scribe ${ }^{94}$.

Staehelin ${ }^{95}$ argues that the straight hair wig first appeared in the fourth Dynasty, but only becomes popular during the fifth Dynasty on statues from Saqqara, and later in the Old Kingdom it supersedes the echelon-curl wig, but this appears to hold true only for stone statues. Furthermore, Fletcher ${ }^{96}$ suggested that the greater number of depictions of male peasant and workers start to occur, wearing either the cropped style or the short round one, but they never wear the shoulder-length hair wig, which being exclusively worn by the elite.

To summering up the previous discussion, it can be concluded that the titles and the costumes of the owner of this false door were popular during the Old Kingdom. Thus, the fifth Dynasty was the preferred date for this false door.

\section{Conclusion}

This study tried to publish and date the false door of Shepsi that was found at Saqqara and presented in the Egyptian Museum at Cairo, on one hand. On the other hand, it tries to describe the different portrayals of the deceased. Moreover, it tried to translate the texts which inscribed on this false door. The most significant of such titles and costumes were prevalent during the Old Kingdom. Additionally, the study suggested the fifth Dynasty as the original date for such a false door according to the titles, and costumes as well.

\footnotetext{
${ }^{82}$ PM III/1, 207; LD II, pl. 10.

${ }^{83}$ PM III/1, 149; LD II, 24; H. Junker, Giza II, Die mastabas der beginnenden V. Dynastie auf dem Westfredhofs, Vienna, 1934. Abb. 31.

${ }^{84}$ PM III/1, pp. 169-70; LD II, Abb. 57.

${ }^{85}$ N. Kanawati, The Rock Tombs of El-Hawawish, the Cemetery of Akhmin, vol. VII, Sydney, 1987, p. 57, pl. 18a.

${ }^{86}$ PM III/2, pp. 499- 500; Borchardt, Statuen, I, pl. 9, pp. 34- 5; J. Capart, L'Art Égyptien choix de Decuments, vol. II, Brussels, 1909, pl. 20.

${ }^{87}$ PM III/2, p. 543; Borchardt, Statuen, I, pl. 13, pp. 45- 46; Mareitte, Mastsbas, p. 224.

${ }^{88}$ PM III/2, p. 724; Borchardt, Statuen, I, pl. 31, p. 102.

${ }^{89}$ PM III/2, p. 724; Borchardt, Statuen, I, pl. 21, pp. 72- 73.

${ }^{90}$ Borchardt, Statuen, I, pl. 37, p. 119.

${ }^{91}$ Borchardt, Statuen, I, pl. 39, p. 127.

${ }^{92}$ It was preferred in wooden statues of the six dynasty. PM III/2, pp. 892- 893; Harvey, Wooden Statues, p. 154, 217- 218; W. K. Smith, A History of Egyptian sculpture and painting in the old kingdom, Boston, $2^{\text {nd }}$ edition, 1949 , pp. 90,205; N. Kanawati, and A. Hassan, the Teti Cemetery at Saqqara, vol. I, the tomb of Nedjet em pet, Ka-aper and others, Sydney, 1996, pp.7- 8; H. Junker, Giza V, Die Mastaba des snb (seneb) und die umliegenden Gräber, Vienna, 1941, p. 140; N. Cherpion, Mastabas et Hypogées d' Ancient Empire le Problem de la Datation, Paris, 1989, pp. 136- 137; H. E. Winlock, Egyptian Statues and Statuettes, New York, 1937, fig. 1.

${ }_{93}$ PM III/ 2, p. 598; Borchardt, Statuen, I, pl. 12, p. 43.

${ }^{94}$ PM III/ 2, p. 457; Borchardt, Statuen, I, pl. 14, pp. 50- 51.

95 Staehelin, Tracht, pp. 20- 28; Harvey, Wooden Statues, p. 83.

96 A. J. Fletcher, Ancient Egyptian Hair: A Study in Style, Form and Function. (unpublished Ph.D. thesis) Manchester: Manchester University, 1995, p. 117.
} 


\section{Bibliography}

Baer, K. (1960). Rank and Title in the Old Kingdom. The Structure of the Egyptian Administration in the Fifth and Sixth Dynasties, Chicago.

Borchardt, L. (1911). Statuen und Statuetten, Catalogue Général des Antiquités Égyptiennes du Musée du Caire, vol. I, Berlin.

Bruner, H. (1982). "Menes" in: Helck, W., and Otto, E., (eds.), Lexikon der Ägyptologie, vol. IV, Otto Harrassowitz and Wiesbaden, p. 46- 48.

C. Aldred, Old Kingdom Art in Ancient Egypt, London, 1949.

Capart, J. (1909). L'Art Égyptien: Choix de Documents, vol. II, Brussels.

Chauvet, V. (2001). "Saqqara" in Redford, D. (ed.), The Oxford Encyclopedia of Ancient Egypt, Vol. III, Cairo, PP. 176- 179.

Cherpion N. (1989). Mastabas et Hypogées d'Ancient Empire: le Problème de la Datation, Paris.

Cherpion, N. (1998). La statuaire privée d'Ancient Empire: Indices de datation, in N. Grimal (ed.) Les Critères de Datation Stylistiques à l'Ancien Empire. Cairo, IFAO: 97-142.

Daoud, K., (2005). Corpus of Inscriptions of the Herakleopolitan Period from the Memphite Necropolis, Oxford.

Daressy, G. (1900). Le Mastaba de Mera, (Mémoires Présentés à 1'Institut Égyptien 3), Cairo.

Davies, N. de G. (1901). The Mastaba of Ptahhetep and Akhethetep at Saqqarah (ASE), Vol. II, London.

Davies, N. de G. (1902). The Rock Tombs at Deri El-Gebrawi, 2 Vols., London.

De Rouge, E., (1866). Recherches sur les monuments qu'on peut attribuer aux six premières dynasties de Manéthon. Paris.

Eaton-Krauss, M. (1976). 'Two Representations of Black-skinned Statues in Ancient Egyptian Painting", JARCE 13, PP. 21-24.

El-Khouli, A., and Kanawati, N. (1989). Quseir el-Amarna. The Tombs of Pepy-ankh and Khewen-wekh, (The Australian Centre for Egyptology, Report 1). Sydney.

Erman, A., and Grapow, H. (1971). Worterbuch der Ägyptischen Sprache im Auftrage der deutschen Akademien, Band II, Leipzig and Berlin.

Excavation at Giza, Vol. V, 1933- 34, Cairo.

Firth, C. M. and Gunn, B. (1926). Teti Pyramid Cemeteries, 2 vols., (Excavations at Saqqara), Cairo.

Fletcher, A. J. (1995). Ancient Egyptian Hair: A Study in Style, Form and Function. (Ph.D. thesis) Manchester: Manchester University.

Garcia, M. (1997). Etudes sur l'Administration le Pouvoir et l'idéologie en Égypte, de l'Ancien au Moyen Empire (Aegyptiaca Leodiensia, 4), Liege.

Gauthier, H. (1929). Dictionnaire des Noms Géographiques Contenus dans les Textes Hièroglyphiques, Vol. VII, Cairo.

Hallström, A. (2017). The False Doors of Hershefnakht, Nyankhanty and Senetites, Uppsala.

Harpure, Y. (1987). Decoration in Egyptian Tombs of the Old Kingdom, London and New York.

Harvey, J. (2001). Wooden Statues of the Old Kingdom, Boston.

Hassan, S. (1936). Excavation at Giza, Vol. II, 1930- 31, Cairo.

Hassan, S. (1953). Excavation at Giza, Vol. VII, 1935- 36, Cairo.

Helck, W. (1954). Untersuchungen zu den Beamtentiteln des agyptischen Alten Reiches (AF18). Gliickstadt.

Helck, W. (1982). "Narmer" in: Helck, W., and Otto, E., (eds.), Lexikon der Ägyptologie, vol. IV, Otto Harrassowitz and Wiesbaden, PP. 348- 50.

Helck, W., (1975). "Bier" in: Helck, W., and Otto, W., (eds.), Lexikon der Ägyptologie, vol. I 
Jacquet-Gordon, H. K. (1962). Les Noms des Domaines Funéraires sous Ancien Empire Égyptien (BdE 34). Cairo.

Jones, D. (2000). An Index of Ancient Egyptian Titles, Epithets and Phrases of the Old Kingdom, 2 vols., BAR International Series 886 (II), Oxford.

Junker, H. (1934). Giza II, Die Mastabas der Beginnenden V. Dynastie auf dem Westfredhofs, Vienna.

Junker, H. (1941). Giza V, Die Mastaba des Snb (seneb) und die Umliegenden Gräber, Vienna.

Kamal, A. B. (1912), "Foullies À Dara et QoÇèir El-Amarna", ASAE 12, p. 128-136.

Kanawati, N. (1987). The Rock Tombs of El-Hawawish, the Cemetery of Akhmin, vol. VII, Sydney.

Kanawati, N. and Abder-Raziq, M. (1998). The Teti Cemetery at Saqqara Vol. III. The Tombs of Efersheshemre and Seankhuiptah, (The Australian Centre of Egyptology: Reports 11), Sydney.

Kanawati, N. and Hassan, A. (1996). The Teti Cemetery at Saqqara, Vol. I, The tomb of Nedjet em pet, Ka-aper and Others, Sydney.

Kaplony, P. (1976). Studien zum Grab des Methethi (Monographien der Abegg-Stiftung Bern 8), Bern.

Legrain, G. (1899). "Notes Arcehologiques Prises au Gebel Abu Fodah", ASAE 1, p. 1- 14.

Lepsius, C.R. (1849). Denkmäler aus Ägypten und Athiopien. Band II, Berlin.

Mariette, A. and Maspero, G. (1885). Les Mastabas de l'Ancien Empire, Paris.

Montet, P. (1951). Géographie de l'Éypte Ancienne. Vol. I, Paris.

Murray, M. A. (1908). Index of Names and Titles of the Old Kingdom, BSAE 1, London.

Perrot G. and Chipiez, Ch. (1882/83). The History of Art in Ancient Egypt, 2 Vols., London.

Petrie, W. F. (1898). Deshasheh 1897 (EEF 15), London.

Piacentini, P. (1993). Zawiet el-Mayetin, (SEAP, Series Minor 4), Pisa.

Piacentini, P. (1997). Enquête sur les scribes dans la société égyptienne de l'Ancien Empire (les Nécropoles Memphites), 3 vols., Paris.

Porter, B. and Moss R. (1978). Topographical Bibliography of Ancient Egyptian Hieroglyphic Texts, Reliefs, and Panting, vol. III, Memphis, Part II, Saqqara to Dahshûr, Oxford.

Quibell, J. and Hayter K. (1927). Excavation at Saqqara, Teti Pyramid, North Side, Cairo.

Ranke, H., (1935). Die Ägyptischen Personennamen, vol. I, Glückstadt.

Rose, F. (2002). The Art of Ancient Egypt, New York.

Simpson, W.K. (1980). Giza Mastabas, Vol. III, The mastaba of Kawab and Khaf Khufu I and II, Boston.

Smith, W. K. (1949). A History of Egyptian Sculpture and Painting in the Old Kingdom, $2^{\text {nd }}$ edition, Boston.

Staehelin, E. (1966). Untersuchungen zur ägyptischen Tracht im Alten Reich, MÄS 8, Berlin.

Steindorffe, G. (1928). Die Kunst der Ägypter, Leipzig.

Strudwick, N. (1985). The Administration of Egypt in the Old Kingdom. The Highest Titles and their Holders, London.

Tassie, G. J. (2005). Single Mother Goddesses and Divine Kingship: the Sidelock of youth and the Maternal Bond, in: Cooke, A. and Simpson, F. (eds.) Current Research in Egyptology II. Oxford, PP. 65-74.

Teeter, E. (1994). "Egyptian Art" in: Art Institute of Chicago Museum Studies, vol. 20, PP. 13- 31.

Vandier, J. (1958). Manuel d'Archéologie Égyptienne, Tome III, les Grandes Époques: la Statuaire, Paris, 
Ward, W., (1982). Index of Egyptian Administrative and Religious titles of the Middle Kingdom, Beirut.

Weil, A. (1908). Die Veziere des Pharaonenreiches, Strasbourg.

Weill, R. (1908). Les Origines de l'Égypte Pharaonique, Première Partie: Les I et III Dynasties Égyptiennes. Paris.

Wiebach, S., (2001). "False Door" in: Redford, D. (ed.), the Oxford Encyclopedia of Ancient Egypt, Vol. I, Oxford, PP. 498- 501.

Winlock, H. E. (1937). Egyptian Statues and Statuettes, New York. 
Figure 1: Photograph of the false door of Shepsi (after the courtesy of the Egyptian Museum).

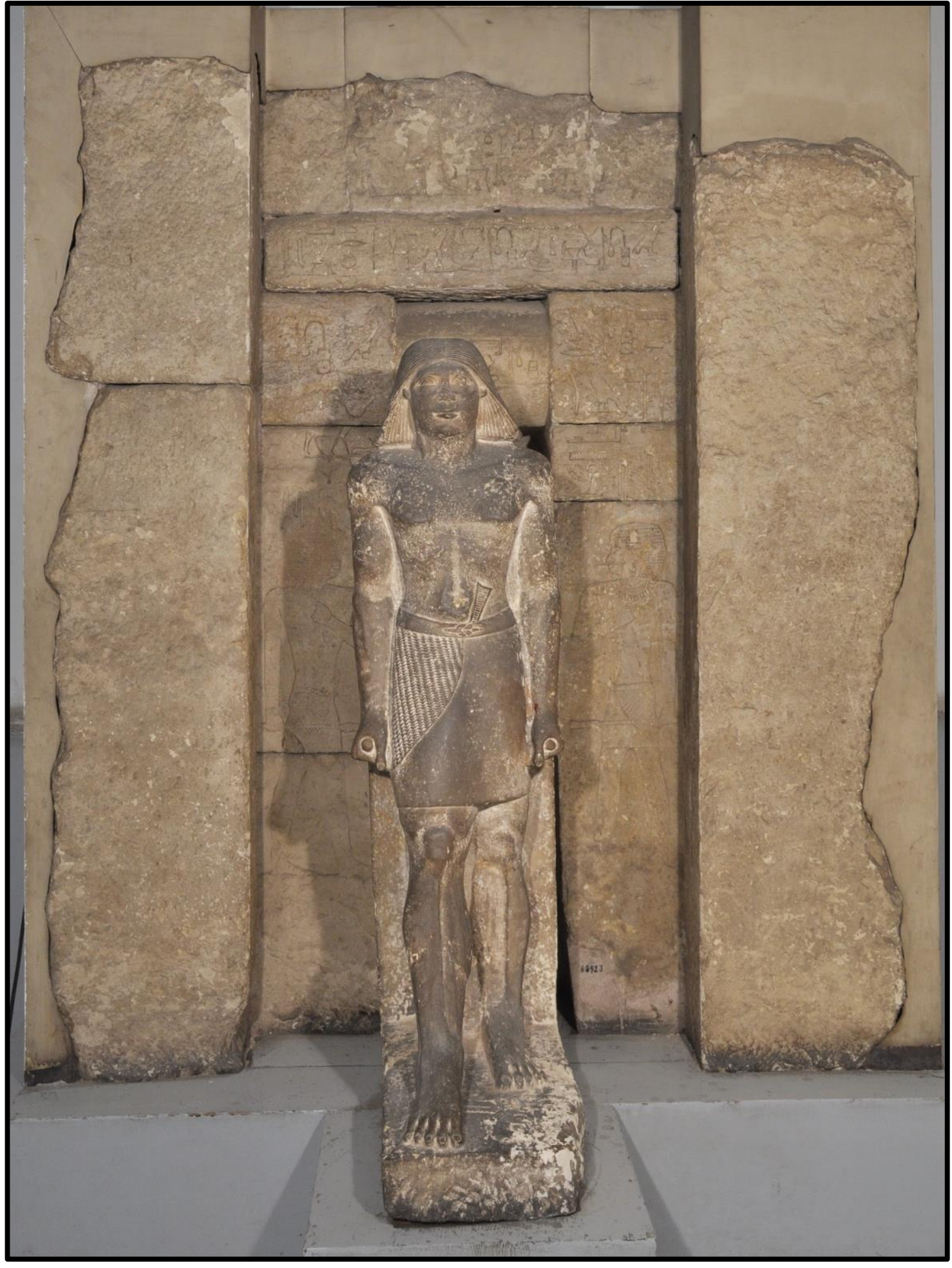


Figure 2: Photograph of the statue of Shepsi (after the courtesy of the Egyptian Museum).

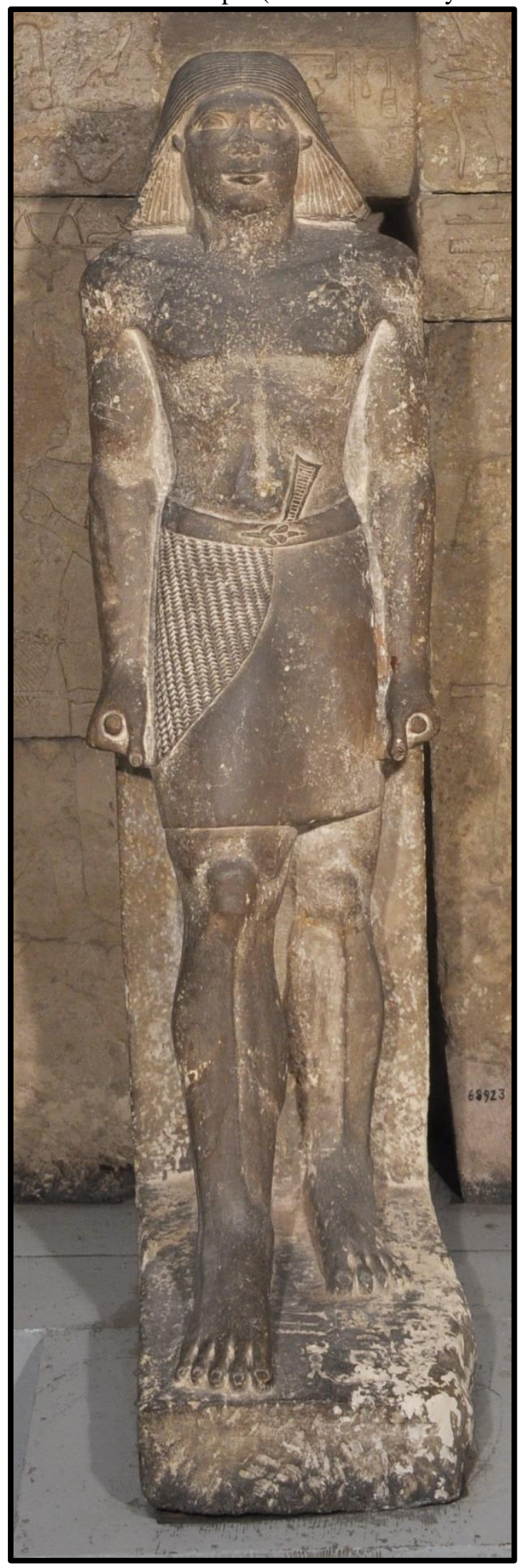


Figure 3: Photograph of the pedestal of the statue of Shepsi (after the courtesy of the Egyptian Museum)

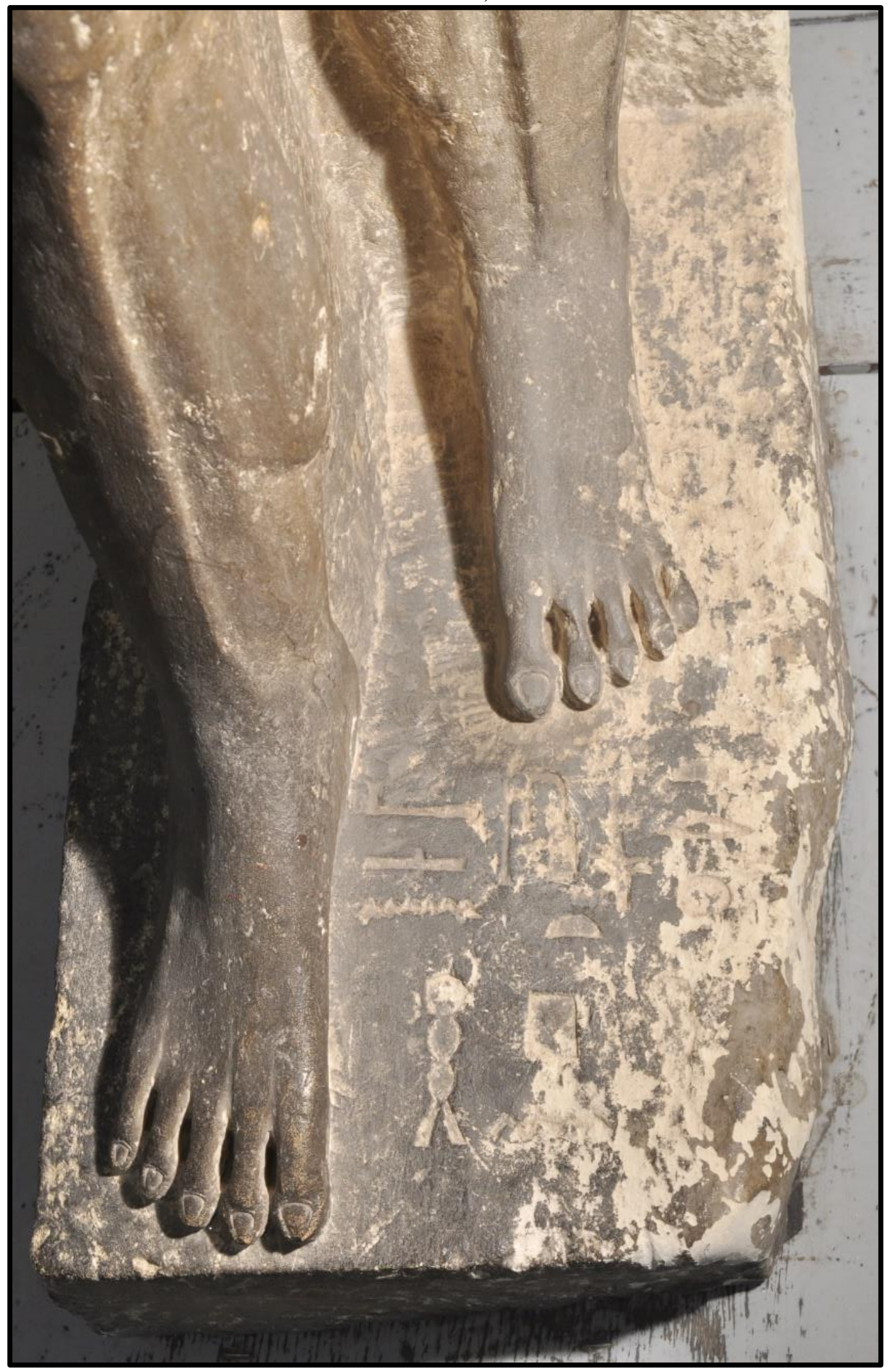


Figure 4: Facsimile of the false door of Shepsi @Mina Samy.

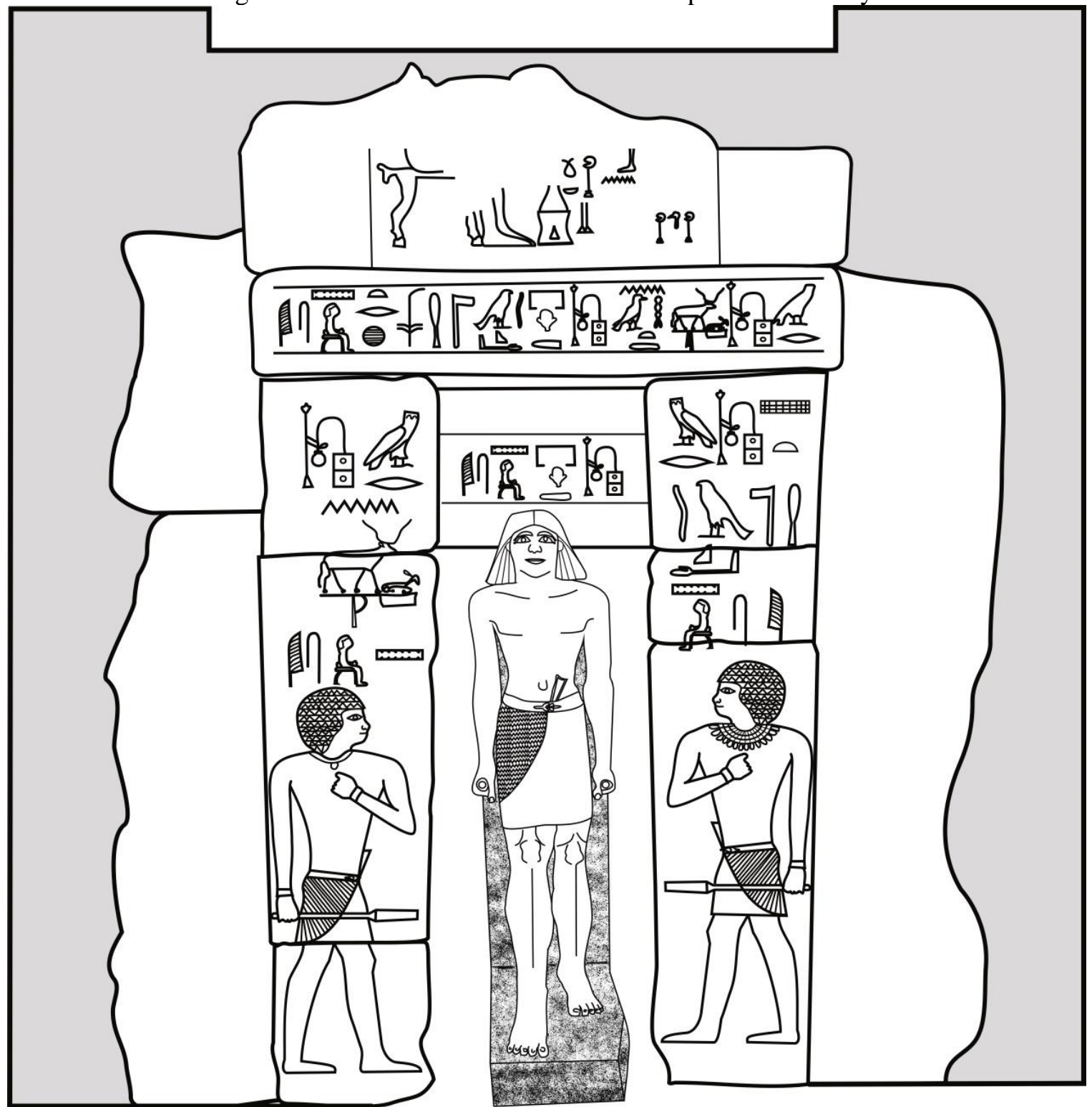

